\title{
MEETING NEW READERS IN THE TRANSITION TO DIGITAL NEWSPAPERS: LESSONS FROM THE ENTERTAINMENT INDUSTRY
}

\author{
Lecciones que la prensa digital puede aprender de la \\ industria del entretenimiento
}

\section{Loreto Corredoira and Sanjay Sood}

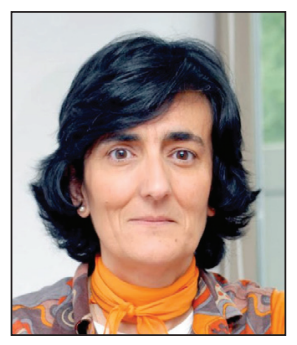

Loreto Corredoira is professor of Communication Law at the Complutense University of Madrid and professor of several masters in Chile and Perú. She is also a degree professor at the universities of Alicante, Valencia and Pontificia de Salamanca. Professor of the Master ejecutivo en gestión de empresas de comunicación (Megec) at University of Navarra, and at the Master on audiovisual post-production, at Abat Oliva University, Barcelona. Visiting scholar at University of California Berkeley, since 1998, and at University of California Los Angeles, since 2014. She is author of popular articles like Uso de Twitter y Facebook por los medios iberoamericanos; Derecho de la Información. Sujetos y medios; and various books like Paradojas de internet: Reflexiones después de una comparecencia en la comisión internet del senado; La protección del talento; and El patrocinio. http://orcid.org/0000-0003-1198-7659

Universidad Complutense de Madrid, Facultad de Ciencias de la Información Av. Complutense, s/n. Ciudad Universitaria. 28040 Madrid, España loretoc@ucm.es

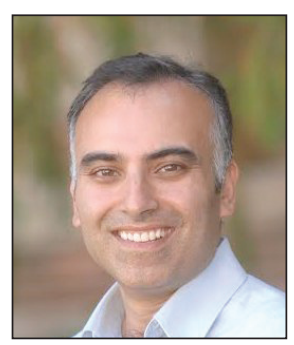

Sanjay Sood's research and teaching expertise lies in the area of brand equity and consumer decision making. Using psychological principles, he examines how firms can best build, manage, and leverage strong brand names. Member of the editorial review boards of Journal of consumer research, Journal of marketing, Journal of consumer psychology and Journal of marketing research. Ph.D. in marketing from the Graduate School of Business, Stanford University. MBA degree from Northwestern University and BS degree in electrical engineering from the University of Illinois, Urbana-Champaign. He has won several awards for excellence in teaching and student mentoring, including the Neidorf decade teaching award at UCLA. He has work with several leading marketing companies, including Intel, Starbucks, Disney, Levi-Strauss, Microsoft, and Kaiser Permanente. http://orcid.org/0000-0002-3418-6347

UCLA Anderson School of Management 110 Westwood Plaza, Gold Hall, Suite B120, Los Angeles, CA 90095-1481, USA sanjay.sood@anderson.ucla.edu

\begin{abstract}
In this work, carried out at the University of California Los Angeles (UCLA) Center for Management of Enterprise Media, Entertainment, and Sports (Memes), we suggest that there is hope and reason for media companies to expect a recovery from the current crisis. As journalists and researchers in communication, we are concerned about newspapers' sustainability, and we refuse to consider a future scenario without the press. According to this objective we focus on the entertainment industry with the goal of learning from it how to survive and even grow despite freely available content on the Web. We consider the unstoppable growth in users and revenue experienced by Netflix, Amazon and iTunes, and pull from it lessons learned that might help newspapers to navigate the digital landscape. Our hypothesis is that digital newspapers can find new readers in the segment of digital consumers who already "pay" for digital content including streaming movies and television shows. Sales, subscriptions, and online rentals experienced significant growth in 2013, bringing them closer to the sales figures of hardware such as DVDs and blu-ray discs. And, although piracy is an issue in the entertainment industry, there remains room for revenue growth.
\end{abstract}

\section{Keywords}

Digital movies; Streaming; iVOD; Video; Digital consumers; Users; Readers; Piracy; Newspapers; Press; Media; Digital newspapers; Cybermedia; Pricing models; Entertainment industry. 


\section{Resumen}

En este trabajo realizado en el Center for Management of Enterprise Media, Entertainment, and Sports (Memes), University of California Los Angeles (UCLA), sugerimos que hay esperanza y razones para que las empresas periodísticas se recuperen de la crisis actual. Como periodistas e investigadores en Comunicación, nos preocupa la sostenibilidad de los periódicos, y no queremos ni pensar en un futuro escenario sin prensa. De acuerdo con este objetivo nos hemos centrado en la industria del entretenimiento con la idea de aprender de ella cómo sobrevivir o incluso crecer a pesar de que muchos contenidos estén disponibles gratuitamente en la Web. Considerando el imparable crecimiento experimentado por Netflix, Amazon o iTunes, tanto en número usuarios como de ingresos durante este mismo período de tiempo, si los periódicos pueden imaginar el modo de navegar en el indiscutido panorama digital, hay razones para ser optimistas. La hipótesis es que es posible encontrar nuevos lectores en el segmento de consumidores digitales que "pagan" por contenidos digitales, como es patente en el estudio realizado en el mercado de Estados Unidos, que presentamos aquí, en concreto ventas y streaming online de cine. Las ventas, suscripciones y alquileres online de pago han subido notablemente en 2013, tanto que se está acercando a las cifras de venta de soportes físicos: DVDs y discos blu-ray. Por otro lado, sostenemos en paralelo que la piratería no ha terminado con la industria cinematográfica, pese a que persiste un elevado número de descargas ilegales, y esto es así porque hay margen para crecer en el segmento móvil digital.

\section{Palabras clave}

Cine digital; Copyright; Piratería; Periódicos; Prensa; Medios; iVOD; Video; Plataformas de cine; Streaming; Consumidores; Usuarios; Lectores; Diarios digitales; Cibermedios; Modelo de precios; Industria del ocio.

Corredoira, Loreto; Sood, Sanjay (2015). "Meeting new readers in the transition to digital newspapers: Lessons from the entertainment industry". El profesional de la información, v. 24, n. 2, pp. 138-148

http://dx.doi.org/10.3145/epi.2015.mar.07

\section{Introduction}

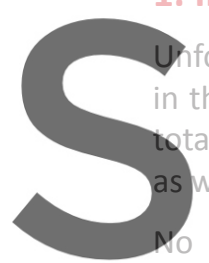

fortunately revenues for $n$ the US since 1940. After a circulation dropped again ell as in Europe (AEDE, 2013 doubt the drop had something to do with the com-

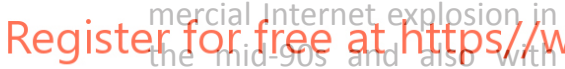
the 2.0. social web in 2002; social networks, blogs, and other innovations provide access to the news and have significantly affected the media business.

The rise of the Internet and the availability of information for free made everybody wonder: Has the press already reached its peak? Is this news market totally saturated, in decline, or can it grow again?

A number of headlines ${ }^{2}$ have forecasted a black future for print media. For example, a sarcastic website, News paper death watch, (figure 2) has announced the death of newspapers every year since 2007. Consultants like Ross Dawson have also forecasted the total death of "paper" in
30 years (Dawson, 2013?). However, a more accurate analy-
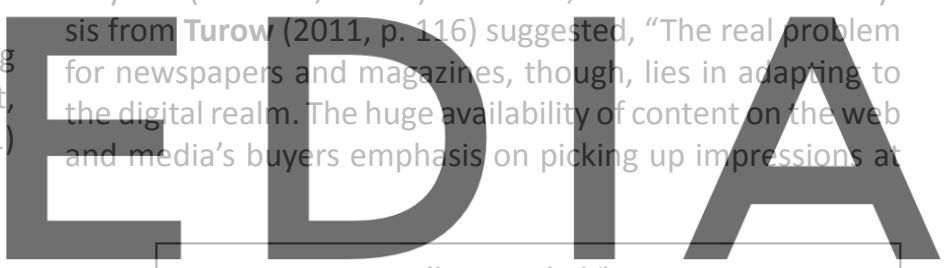

Daily circulation

Sunday

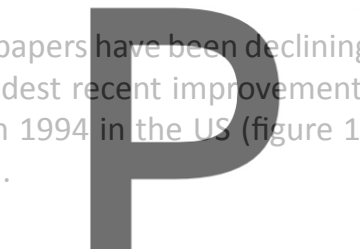

Number of daily newspapers

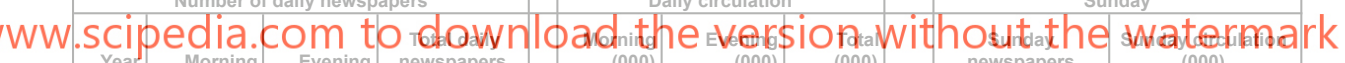

\begin{tabular}{|c|c|c|c|c|c|c|c|c|}
\hline Year & Morning & Evening & newspapers & $(000)$ & $(000)$ & $(000)$ & newspapers & $(000)$ \\
\hline $2011^{*}$ & 931 & 451 & 1.382 & 40.321 & 4.100 & 44.421 & 900 & 48.510 \\
\hline 2010 & $\mathrm{NA}$ & $\mathrm{NA}$ & $\mathrm{NA}$ & $\mathrm{NA}$ & $\mathrm{NA}$ & $\mathrm{NA}$ & NA & NA \\
\hline 2009 & 862 & 525 & 1.387 & 40.269 & 5.383 & 45.653 & 911 & 46.164 \\
\hline 2008 & 872 & 546 & 1.408 & 42.757 & 5.840 & 48.597 & 902 & 49.115 \\
\hline 2007 & 867 & 565 & 1.422 & 44.548 & 6.194 & 50.742 & 907 & 51.246 \\
\hline 2006 & 833 & 614 & 1.437 & 45.441 & 6.888 & 52.329 & 907 & 53.179 \\
\hline 2005 & 817 & 645 & 1.452 & 46.122 & 7.222 & 53.345 & 914 & 55.270 \\
\hline 2004 & 814 & 653 & 1.457 & 46.887 & 7.738 & 54.626 & 915 & 57.754 \\
\hline 2003 & 787 & 680 & 1.456 & 46.930 & 8.255 & 55.185 & 917 & 58.495 \\
\hline 2002 & 777 & 692 & 1.457 & 46.617 & 8.568 & 55.186 & 913 & 58.780 \\
\hline 2001 & 776 & 704 & 1.468 & 46.821 & 8.756 & 55.578 & 913 & 59.090 \\
\hline 2000 & 766 & 727 & 1.480 & 46.772 & 9.000 & 55.773 & 917 & 59.421 \\
\hline 1999 & 736 & 760 & 1.483 & 45.997 & 9.982 & 55.979 & 905 & 59.894 \\
\hline 1998 & 721 & 781 & 1.489 & 45.643 & 10.539 & 56.182 & 898 & 60.066 \\
\hline 1997 & 705 & 816 & 1.509 & 45.434 & 11.290 & 56.728 & 903 & 60.486 \\
\hline 1996 & 686 & 846 & 1.520 & 44.785 & 12.198 & 56.983 & 890 & 60.798 \\
\hline 1995 & 656 & 891 & 1.533 & 44.310 & 13.883 & 58.193 & 888 & 61.229 \\
\hline 1994 & 635 & 935 & 1.548 & 43.382 & 15.924 & 59.305 & 886 & 62.295 \\
\hline 1993 & 623 & 954 & 1.556 & 43.094 & 16.718 & 59.812 & 884 & 62.566 \\
\hline 1992 & 596 & 996 & 1.570 & 42.388 & 17.777 & 60.164 & 891 & 62.160 \\
\hline 1991 & 571 & 1.042 & 1.586 & 41.470 & 19.217 & 60.687 & 875 & 62.068 \\
\hline 1990 & 559 & 1.084 & 1.611 & 41.311 & 21.017 & 62.328 & 863 & 62.635 \\
\hline
\end{tabular}

Figure 1. World newspaper circulation (2012). Source: Editor and Publisher International Yearbook http://www.editorandpublisher.com/databook 


\section{Newspaper Death Watch}

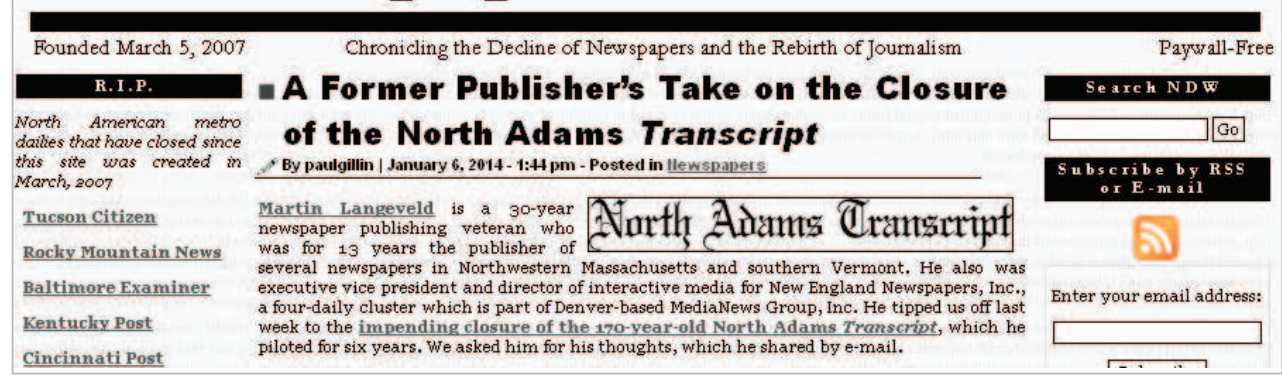

Figure 2. http://newspaperdeathwatch.com

the lowest possible cost-per-thousand (CPMs) impressions meant that advertising in a digital environment could not possible support their organizations the way it did in the print sphere".

With all of the doom and gloom we, the authors, have been wondering if the newspaper business has a chance to be a viable business again: Is the press always going to be primarily dependent on advertising, for better or worse? Is there any chance of new income streams from other sources and other business areas (e-commerce, online marketing, etc.) that would allow newspapers editors to keep quality standaras high and maintain newsrdon trary, are we at the very end of the have to shrink?

After Masanell, Goyanes, Peinado

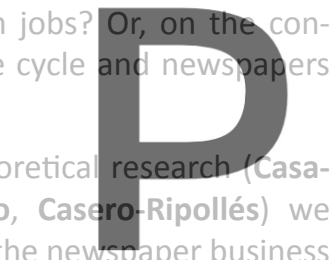

to rise again. As journalism and communication scholars we

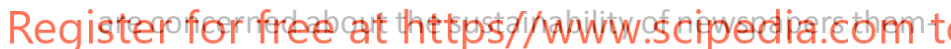
selves; we do not want to think of a future scenario without the press. Accordingly, we have focused on the entertainment industry as a basis for learning how to survive or even thrive when content is available for free online. Consider the increased number of users and growth in revenues by Net-

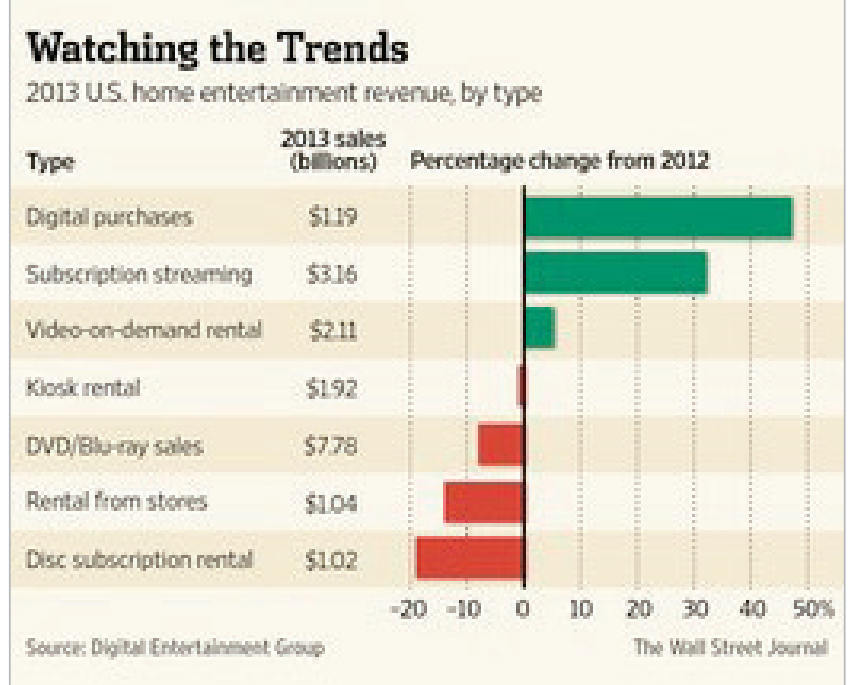

Figure 3. Watching the trends, The Wall Street journal flix, Amazon, and iTunes. If newspapers can figure out a way to navigate the digital landscape, there are reasons to be optimistic about the future ahead.

\section{The digital consumer segment}

As The Wall Street journal reported recently (Fritz, 2014), online streaming and online sales (legal downloads) are growing, and quickly approaching sales of movies on physical DVDs and blu-ray discs (figure 3).

The bottom line is clear: the consumer is now in control. Kevin Spacey, American actor, addressed this issue in the U.K. last year when discussing the House of Cards success:

"Clearly the success of the Netflix model, releasing the entire season of House of Cards at once, proved one thing: the audience wants the control. They want the freedom. If they want to binge... we should let them binge... And through this new form of distribution, we have demonstrated that we have learned the lesson that the music industry didn't learn: give people what they want, when they want it, in the form they want it in,

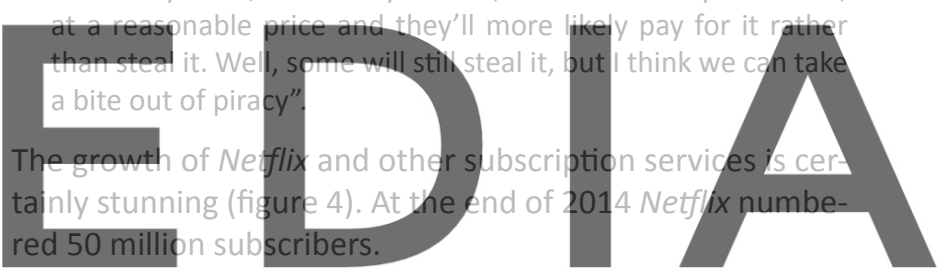

\section{download the version without the watermark} us internet Users Who subscribe to video Services. by Type. Sep 2012

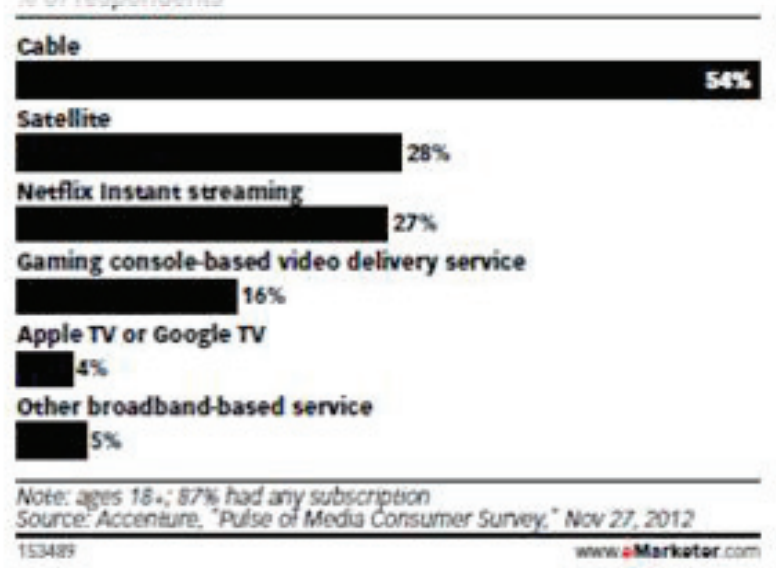

Figure 4. Growth of video services. Source: eMarketer.com

\begin{tabular}{l|l|}
$\begin{array}{l}4 \text { of } 10 \text { Americans buy newspa- } \\
\text { pers daily, and } 4,6 \text { on Sundays }\end{array}$ & 7 of 10 go to theatres twice a year \\
\hline $\begin{array}{l}4 \text { of } 10 \text { watch daily movies or TV } \\
\text { on legal streaming sites }\end{array}$ & $\begin{array}{l}4 \text { of } 10 \text { buy movies sometimes } \\
\text { on sites such as Amazon Prime, } \\
\text { iTunes }\end{array}$ \\
\hline
\end{tabular}

Figure 5. Average of paid-content use (age >18) (Corredoira; Sood, 2015) 
According to Corredoira and Sood (2015), paid video streamers, either in transactional or subscription models, number approximately 80 million subscribers. Although the piracy ${ }^{3}$ of movies and TV shows is still high, Dahaner and Waldfogel (2012) stated: "we do not see evidence of elevated sales displacement in US box office revenue following the adoption of BitTorrent, and we suggest that delayed legal availability of the content abroad may drive the losses to piracy". Clearly there is a large segment of the population willing to pay for content. Thus, there are avenues for growth even when content is available for free.

When comparing platforms one realizes that news still commands a large market; in the US there is one Netflix subscriber for every two newspaper buyers. Netflix has 44 million users who pay $\$ 7.99$ a month for unlimited streaming; movies, TV shows, cartoons, and documentaries are included in its library. This is the same price of a weekly subscription to The financial times or The New York times. Since the price int is comparable, the challenge then becomes identifying the right set of consumers and targeting those who are willing to pay (figure 5).

this point, we suggest there may be a distinct digital consumer segment for Register newspapers to target (García-De-To.

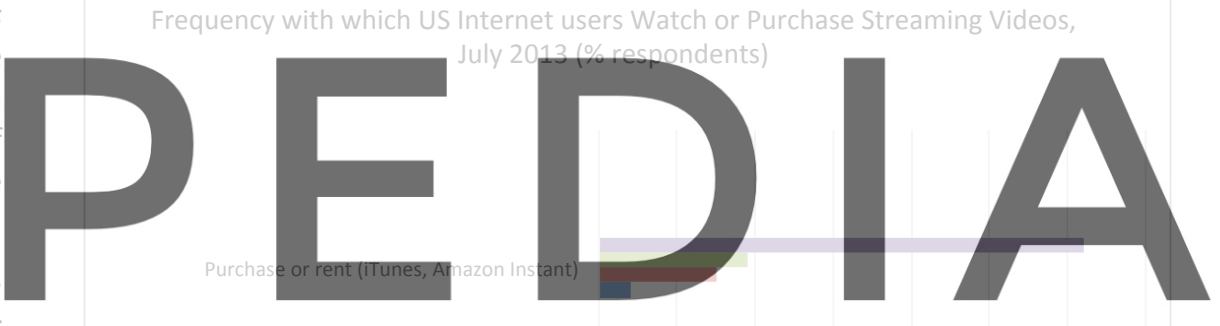

Frequency with which US Internet users Watch or Purchase Streaming Videos,

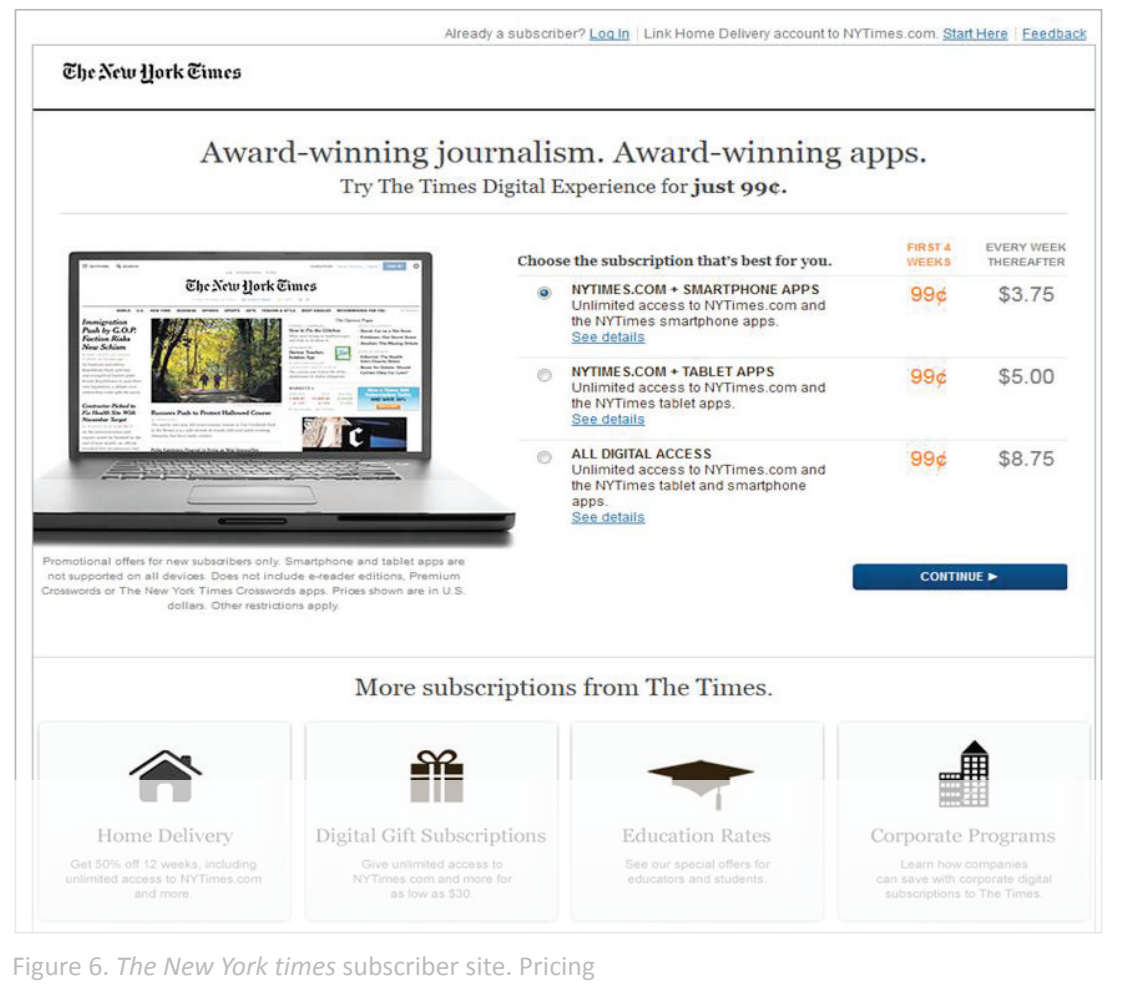

Figure 6. The New York times subscriber site. Pricing

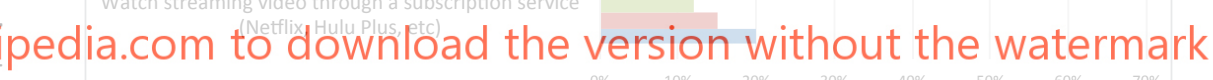

sumer actively seeks out content online and is willing to pay for content. in fact, these consumers over index on consuming content online as shown below (figure 7 and 10). If you examine the correlation between the consumption of premium content by users and the use of various platforms and/or devices, our contention is that a digital subscriber is more likely to buy newspapers and vice versa (Picard, 2006).

Pay particular attention to the streamers activities and the frequency which US TV viewers watch digital video content (by age) (figure 8).

If this digital content consumer segment exists and they are willing to pay for newspaper content, then one way to find these consumers is to target those consuming other forms of entertainment. TV series (such as Downtown abbey, Lost, or Homeland), blockbuster movies (The lord of the rings, The hunger games, or Harry Potter) or entertainment events

never Rarely $\square$ Sometimes $\square$ Ofter

Figure 7. Source: eMarketer.com, The Harris Poll (Harris Interactive) press release Aug 26, 2013

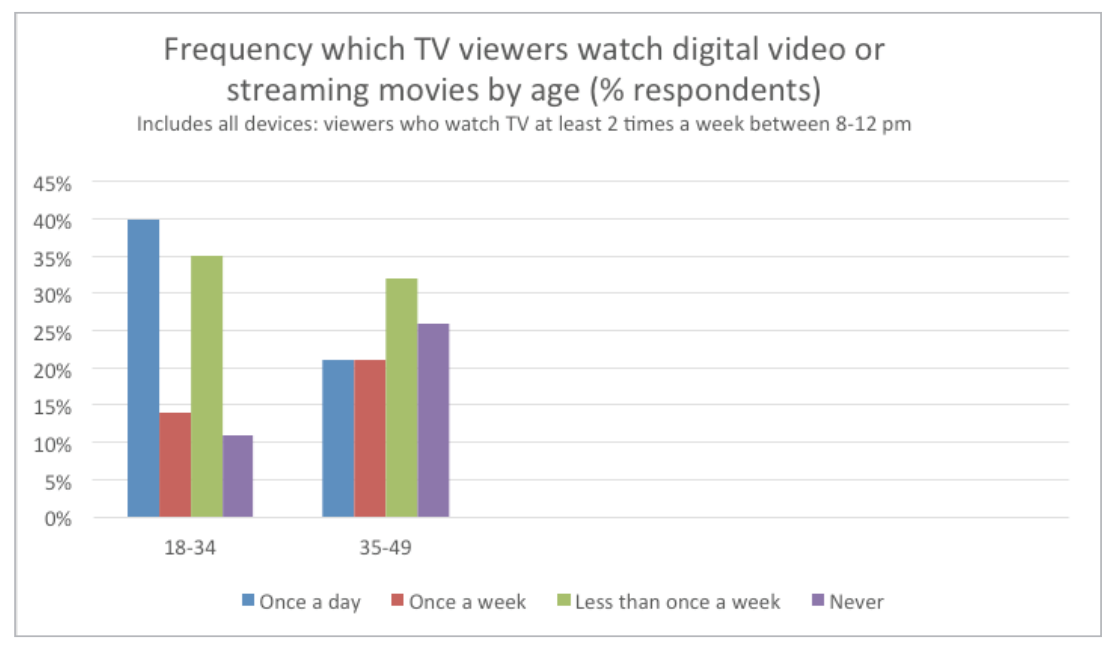

Figure 8. IpsosMediaCT, The two sides of streaming, July 8, 2013), eMarketer.com 


\begin{tabular}{|c|c|c|c|c|c|c|c|}
\hline \multicolumn{2}{|l|}{$\begin{array}{l}\text { Movies (million } \\
\text { streamers) }\end{array}$} & \multicolumn{2}{|c|}{$\begin{array}{l}\text { Digital news } \\
\text { (thousand subscribers) }\end{array}$} & \multicolumn{2}{|c|}{$\begin{array}{l}\text { Sport } \\
\text { (million subscribers) }\end{array}$} & \multicolumn{2}{|c|}{$\begin{array}{l}\text { Music } \\
\text { (million subscribers) }\end{array}$} \\
\hline Netflix & 48 & The NYT & 727,000 & MLBAM & $>3$ & Pandora One & 2.5 \\
\hline iTunes & 20 & The WSJ & 903,012 & Fox Soccer & n.a. & Spotify & 1 \\
\hline Amazon Prime & 10 & & & Gol TV & n.a. & iTunes Radio & 1 \\
\hline Hulu & 5 & & & & & & \\
\hline Aprox. total & 80 & & & ESPIV & n. & & \\
\hline
\end{tabular}

If the newspaper industry had theme music in 2013, it might use "Been down so long it looks like up to $m e$ " the much-recycled line from a 1920s blues song (Edmonds et al., 2013). stated.

Data released by the Newspaper Association of America $(N A A)^{8}$ in February 2014 showed 2013 gains in Alliance for audited media

Figure 9. US paid digital content subscribers (Corredoira; Sood, 2015) $(A A M)$ total circulation due to the success of digital subscriptions (figures 12 and 13):

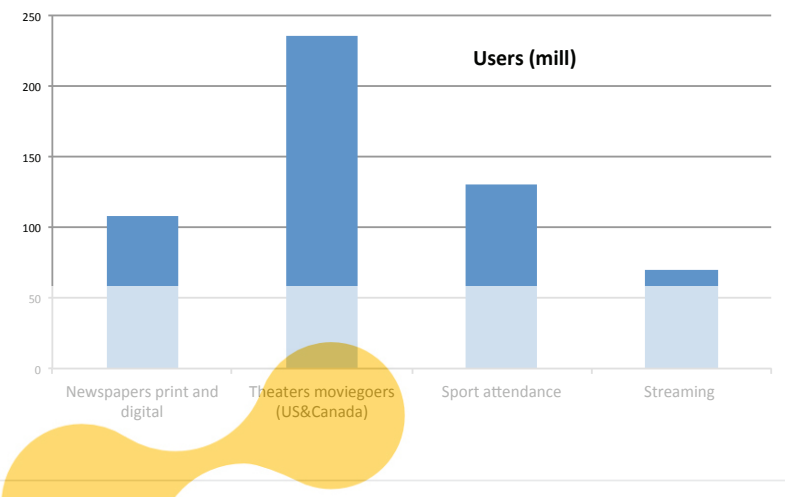

Figure 10. Paid content potential market (Corredoira; Sood, 2015)

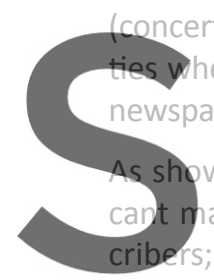

cencerts or opera) are good exapn newspaper readers, subscribers,

As shown (figure 9), music and spo
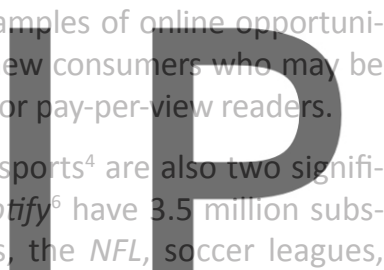

MLB, and the NBA series there are millions more prospects.

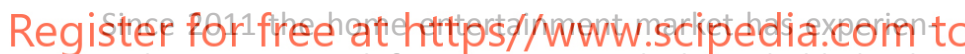
ced an important shift in money spent by household, thanks to streaming, blu-ray and electronic distribution, as The Hollywood reporter said (Arnold, Thomas K., 2012):

"As of Sept. 30, 2012, consumers this year have spent an estimated $\$ 12,342,020,000$ on home entertainment, up from $\$ 12,215,030,000$ in the same period last year".

\subsection{Implications for the newspaper industry}

According to the Newspaper Association of America, young adults (18-34) are still reading newspapers (figure 11).

The growth in the industry appears to be in digital, and this digital consumer is in the younger age bracket. According to the last data available (referred to 2012) 44 million newspapers are sold in the US daily and 48.5 million Sunday editions. The average readership increased in 2013, rising to 95 million daily and 108 million on Sundays.

For digital journalism there was also good news reported in May 2012 by Poynter.com:

"Audit Bureau of Circulations $(A B C)$ : Newspaper circulation rose in the previous six months by $5 \%$ on Sundays. On average, digital circulation now accounts for 14.2 percent of newspapers' total circulation mix, up from 8.66 percent in March 2011. Digital circulation may be tablet or smartphone apps, PDF replicas, metered or restricted-access websites, or e-reader editions." (Beaujon, 2012)

"Average daily combined circulation increased 3 percent compared to the same period a year ago for the six-month period ending Sept. 30, 2013. The gain is based on an NAA analysis of the 541 daily newspapers reporting to $A A M$ for comparable periods. The bottom-line increase was driven by substantial gains in digital circulation among the largest newspapers and more moderate losses in print circulation among the smaller circulation newspapers.'

"Average Sunday circulation for the 508 newspapers reporting for both periods increased 1.6 percent from last year. The gains were due to increased reporting of branded editions and digital non replica circulation by the largest newspapers. Among the 541 newspapers reporting for the period, 120 reported an increase in total daily circulation for the six-month period, while 112 newspapers were up in total Sunday circulation. In both

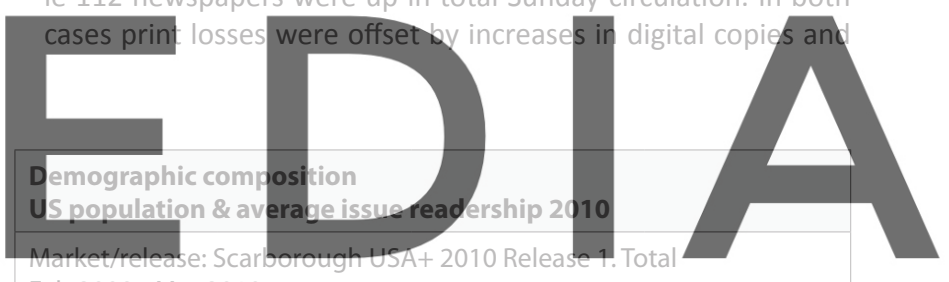
Feb 2009 - Mar 2010

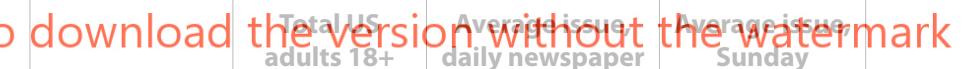

\begin{tabular}{|l|c|c|c|}
\hline Base total & & & \\
\hline Target pop & $232,960,964$ & $95,305,254$ & $108,060,592$ \\
\hline Target \% & $100 \%$ & $100 \%$ & $100 \%$ \\
\hline Index & 100 & 100 & 100 \\
\hline Men & & & \\
\hline Target pop & $113,056,101$ & $48,060,887$ & $50,823,598$ \\
\hline Target \% & $48.5 \%$ & $50.4 \%$ & $47.0 \%$ \\
\hline Index & 100 & 104 & 97 \\
\hline Women & & & \\
\hline Target pop & $119,904,863$ & $47,244,367$ & $57,236,994$ \\
\hline Target \% & $51.5 \%$ & $49.6 \%$ & $53.0 \%$ \\
\hline Index & 100 & 96 & 103 \\
\hline Adults 18 $\mathbf{3 4}$ & & & \\
\hline Target pop & $69,857,082$ & $18,127,761$ & $21,962,532$ \\
\hline Target \% & $30.0 \%$ & $19.0 \%$ & $20.3 \%$ \\
\hline Index & 100 & 63 & 68 \\
\hline Adults > 35 & & & \\
\hline Target pop & $163,103,882$ & $77,177,493$ & $86,098,060$ \\
\hline Target \% & $70.0 \%$ & $81.0 \%$ & $79.7 \%$ \\
\hline Index & 100 & 116 & 114 \\
\hline
\end{tabular}

Figure 11. Demographics. US readership. Newspaper Association of America 
branded editions. Supporting this point, it appears that digital and bundled services are the fastest growing areas in the newspaper industry." ${ }^{8}$

In order to attract the younger demographic and grow subscriptions further, newspapers could mimic the behavior of the entertainment industry and move away from strictly paid services. On February $6^{\text {th }}$ 2014 Times CEO Mark Thompson said ${ }^{9}$ :

"There are now roughly 760,000 people paying to read the Times and its international edition on the web and mobile devices. But the subscriber momentum has slowed since the program was rolled out in March 2011, and the Times is developing new subscription options to achieve scale while also expanding overseas".

Another business model may exist if newspapers focus on reach. According to the latest available data released by Alliance for Audited Media (AAM), the Wall Street journal (WSJ) is the first US newspaper in paid circulation (2.27 million) although USA today is now number one in yearly circulation average thanks in-part to free

\begin{tabular}{|c|c|c|}
\hline & $\begin{array}{c}\text { No. of } \\
\text { Companies }\end{array}$ & YoY \% Change \\
\hline Total Revenue & 17 & $-2 \%$ \\
\hline Total Advertising Revenue & 17 & $-6 \%$ \\
\hline Total Print Newspaper Advertising & 17 & $-9 \%$ \\
\hline Retail & 17 & $-8 \%$ \\
\hline National & 17 & $-12 \%$ \\
\hline Classified & 17 & $-8 \%$ \\
\hline Automotive & 17 & $-8 \%$ \\
\hline Real Estate & 17 & $-13 \%$ \\
\hline Recruitment & 17 & $-7 \%$ \\
\hline Other Classified & 17 & $-5 \%$ \\
\hline Total Digital Advertising & 17 & $4 \%$ \\
\hline Pure-Play Digital Advertising & 10 & $20 \%$ \\
\hline Niche Publications & 7 & $-5 \%$ \\
\hline Direct Marketing & 11 & $-1 \%$ \\
\hline Non-Daily/Weekly & 8 & $-6 \%$ \\
\hline Total Circulation Revenue & 17 & $5 \%$ \\
\hline Print Subscription \& Single-Copy Sales & 11 & $-14 \%$ \\
\hline Bundled & 7 & $499 \%$ \\
\hline Digital-Only & 12 & $275 \%$ \\
\hline New Revenue & 17 & $8 \%$ \\
\hline Distribution & 11 & $-2 \%$ \\
\hline Digital Agency/Marketing Services & 9 & $91 \%$ \\
\hline Event Marketing & 7 & $-9 \%$ \\
\hline E-commerce & 3 & $20 \%$ \\
\hline Commercial Printing & 11 & $-3 \%$ \\
\hline Other Not Listed & 12 & $-3 \%$ \\
\hline Mobile Ad Rev. & 13 & $100 \%$ \\
\hline
\end{tabular}
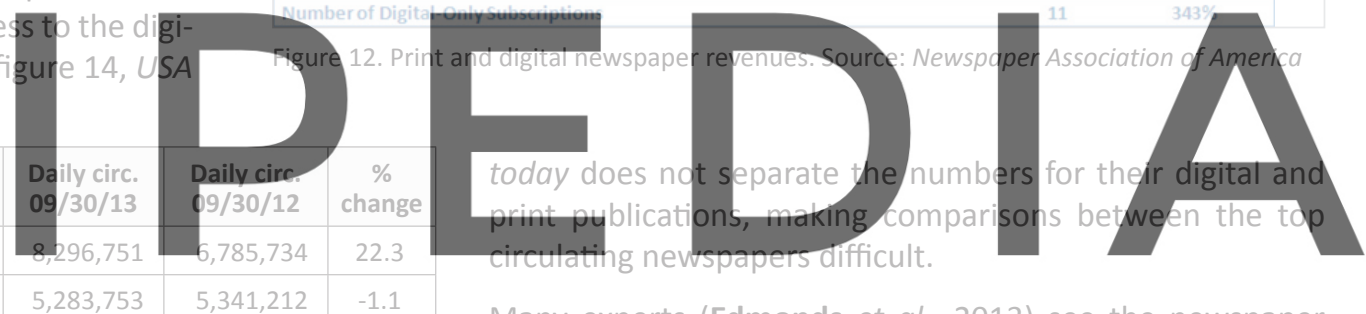

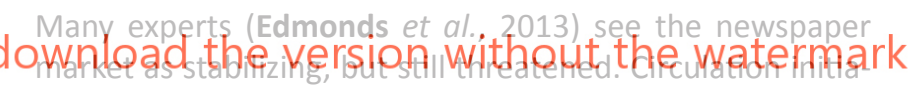

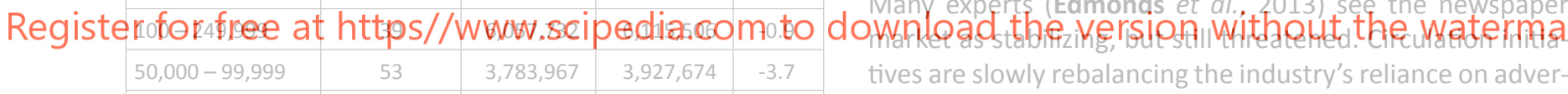

\begin{tabular}{|l|r|r|r|r|}
\hline $25,000-49,999$ & 103 & $3,577,587$ & $3,750,157$ & -4.6 \\
\hline Less than 25,000 & 326 & $4,303,658$ & $4,477,749$ & -3.9 \\
\hline Daily total & $\mathbf{5 4 1}$ & $\mathbf{3 1 , 3 0 3 , 4 4 8}$ & $\mathbf{3 0 , 3 9 8 , 0 3 2}$ & $\mathbf{3 . 0}$ \\
\hline
\end{tabular}

Figure 13. Total daily circulation was up 3 percent year-to-year [and Sunday circulation 1.6 percent] among 541 daily papers reporting results to the Association of Audited Media (AAM) for the six-month period ending Sept. 30, 2013 and September 30, 2013.

tising over circulation as a revenue source. It will be some years until the industry comes close to an international norm. The industry might consider what was implemented in 2012 by The New York times, a 50/50 circulation/advertising split (a small percentage of revenue also comes from other sources) $)^{10}$.

\subsection{The mobile opportunity for content industries}

One area where the newspaper industry could actually hold an

\begin{tabular}{|l|c|c|c|c|c|}
\hline \multicolumn{1}{|c|}{ Newspaper } & Company & $\begin{array}{c}\text { Average circulation } \\
\text { (Sept 2013) }\end{array}$ & Print & Paywall & $\begin{array}{c}\text { Digital } \\
\text { subscribers }\end{array}$ \\
\hline USA today & Gannet Co & $\begin{array}{c}2.9 \text { million } \\
\text { (print }+ \text { free digital } \\
\text { access) }\end{array}$ & n.a. & No & 0 \\
\hline WSJ & News Corp. & $\begin{array}{c}2.4 \text { million }\left(1{ }^{\text {st }} \text { in }\right. \\
\text { paid circulation) }\end{array}$ & $1,480,000$ & Yes & $\begin{array}{c}903,207 \\
(2014)\end{array}$ \\
\hline The New York times & NYTimes Co. & 1.9 million & 727,000 & Yes & $1,254,506$ \\
\hline
\end{tabular}
advantage over entertainment is in the mobile phone segment.

According to SenseMaker ${ }^{11}$ and our research on audiovisual content:

"media consumption trends continue to change rapidly, particularly by the increase today in mobile technology use. Scarborough's extensive population allows researchers to look at the audience of different media sources across platforms". 


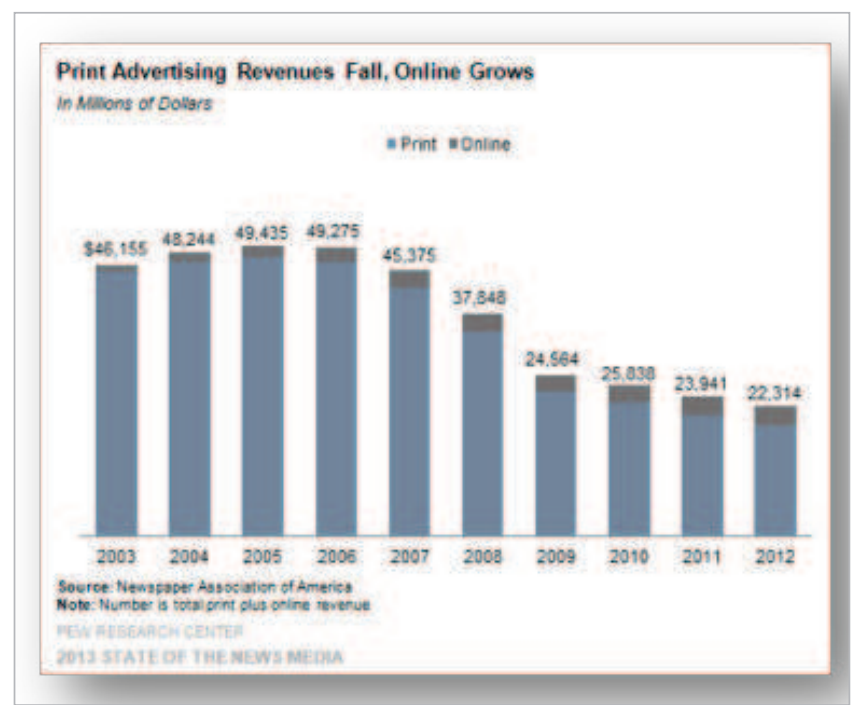

Figure 15. Advertising revenues. State of the News Media 2013

http://w/w/stateofthemedia org/2013/new/spapers-stabilizing-but-stillthreatened/1-print-advertising-fall-online-grows-copy-5

The vast majority of US adults, 164 million (69\%), read newspaper media content in print or online in a typical week, or access it on mobile devices in a typical month.

The majority (59\%) of US young adults, ages 18-24, read newspaper media content in print or online in a typical

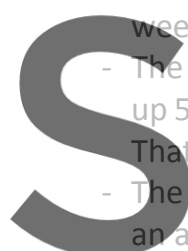

week, or access it on mobile device

oblle newspaper audience

at totals 34 million adults.

US mobile audience skews vr

adult newspaper mobile user
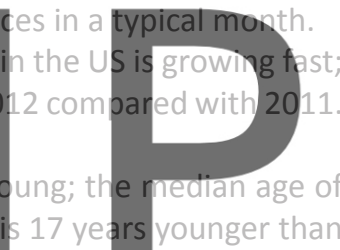

the print reader.

Those who are newspaper mobile-exclusive -that is,

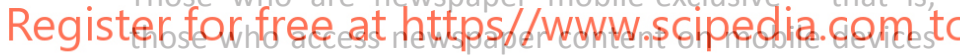

only - are younger by four more years (with a median adult age of 33). That audience grew by $83 \%$ in the US in

2012 compared with 2011.

Overall, the total newspaper media audience in a typical week (excluding mobile) dipped 2\% in 2012 from 2011, a change in line with television media and less than radio.

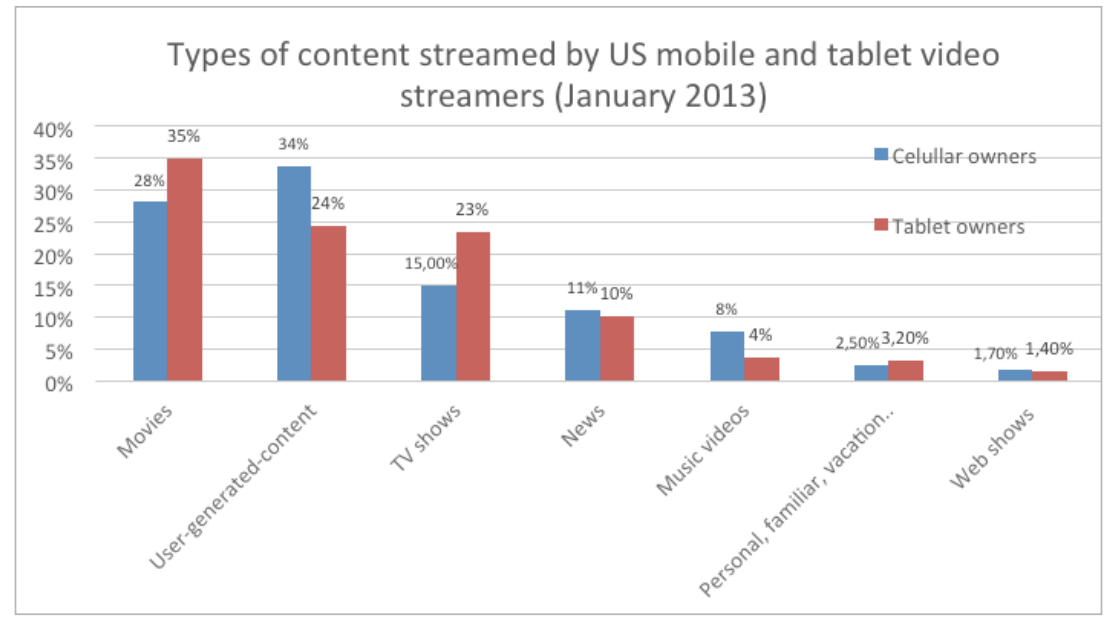

Figure 17. Types of content streamed by US mobile and tablet video streamers (January, 2013)

\begin{tabular}{|c|c|c|c|}
\hline Tablet & Smartphone & PC or laptop & TV \\
\hline $\begin{array}{l}\text { Movies } \\
\text { TV shows }\end{array}$ & $\begin{array}{l}\text { UGC (user generated } \\
\text { content) (YouTube) } \\
\text { News } \\
\text { Music videos }\end{array}$ & $\begin{array}{l}\text { Short video clips } \\
\text { UGC }\end{array}$ & $\begin{array}{l}\text { Full-length } \\
\text { movies }(72 \%) \\
\text { Live content } \\
(68 \%)\end{array}$ \\
\hline
\end{tabular}

Figure 16. Preferred content by screen. Data from Accenture, DigitalSmith, eMarketet

When the mobile audience is included, through data that are collected monthly, the decline in total newspaper audience is cut by more than half to less than $1 \%$.

These data points do not reflect the spike in sales for mobile devices in the past six months. It is likely that when new Scarborough data become available later in the year, the mobile component of the newspaper media audience will show continued growth.

In fact, recent reports (DigitalSmiths, Accenture) revealed that news content is in the top preferences for consumption among smartphone users.

In addition, among the streamers the most viewed content for mobile devices is video, user-generated content (UGC), $T V$, and in fourth place is news.

As Mojiva's CEO, David Gwozdz ${ }^{12}$ stated in 2012 and the

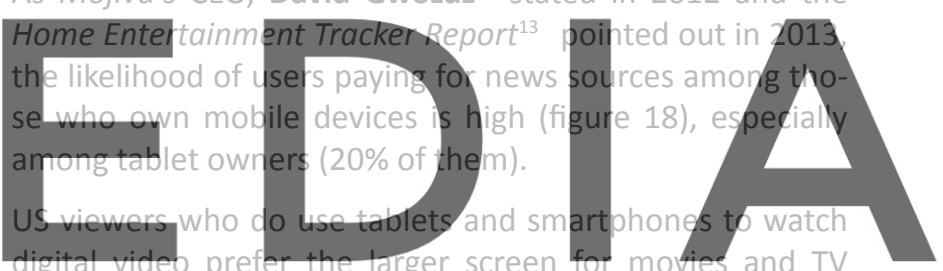

shows and the smaller one for shorter-form content such as

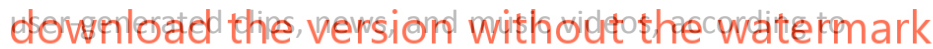
a study (Rovi Corporation, 2013). This data underscores the importance viewers attach to screen size when it comes to premium content.

\section{Lessons from the entertainment industry}

As we have said before, a newspaper has to identify the right set of consumers and target those persons who are willing to pay. There are lessons we have learned from the entertainment industry in the US which can be used to "package" the news product.

\subsection{Lessons about user's care}

\section{Consumer and flexibility}

What really matters is the consumer. In this regard, we note how some entertainment providers have improved user policies for subscribers (Amazon Prime, Hulu Plus), which includes the possibility of upgrading services. One good example from streaming media is Netflix's four screens option for just $\$ 4$ month more. This type of usage flexibility is convenient for clients who 
have several devices in different locations and want the same subscription to simultaneously stream content. This flexibility allows the user to decide when and how to see, read, and listen to their favorite programs.

\section{Availability}

Availability is the keyword for online content. New agreements must be made with industry partners that allow innovative methods for availability (i.e. House of Cards Season 2) where pricing and usability allow the consumers to control when and where they consume the news.

\section{Usability}

Another important lesson we can learn from the success of audiovisual online distribution is the variety of platforms (Netflix and iTunes work on Windows, Apple, Google, etc.) and even though the competition among them is high, the interface among different platforms is compatible - users don't need extra plugins or software.

\section{Pricing}

Price has been a competitive advantage in

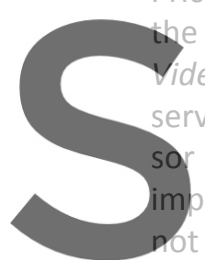
e success of platforms like $A$

deo, not to mention Netflix

rvices. According to IT blo

Enrique Dans (2014), pricin

ortant in the struggle ag

only agree (Corredoira, 2011 )

believe price has been a competitive advanta.
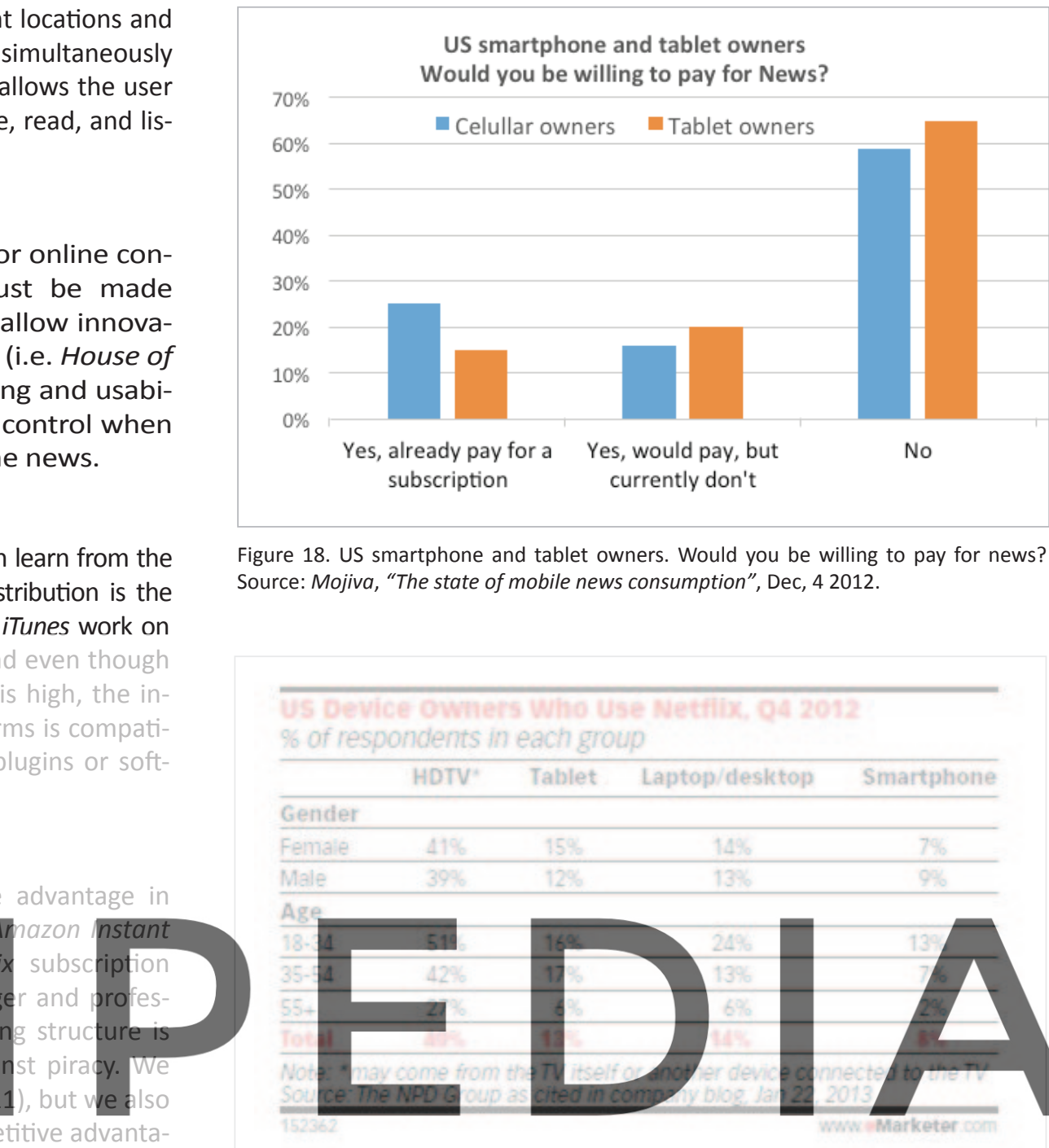

Figure 18. US smartphone and tablet owners. Would you be willing to pay for news? Source: Mojiva, "The state of mobile news consumption", Dec, 42012.

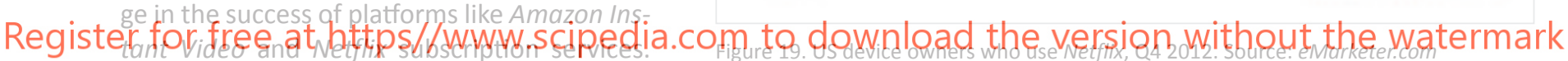

Consumers have many entertainment choices

in the US, and the costs of each option are shown in figure 20.

The current unit price and volume of newspapers sold barely covers the production cost of a single edition. However, new pricing could be developed. News online could be bundled with other services, enhanced for content, or extended for free trial periods. Portals like Netflix and VUDU (similar to Youzze or Wuaki TV in Spain) have attracted new

\begin{tabular}{|l|l|}
\hline 1 movie ticket at the theaters & $\$ 15$ \\
\hline 1 movie rental from iTunes or Amazon Prime & $\$ 2.99$ to 6.99 \\
\hline 1 month Netflix & $\begin{array}{l}\$ 7.99 \text { (2 screens, } 6 \\
\text { devices) }\end{array}$ \\
\hline $\begin{array}{l}1 \text { movie purchase from iTunes or Amazon } \\
\text { (HD or not) }\end{array}$ & From \$6.99 \\
\hline 1 weekly premium Financial times & $\$ 10.95$ \\
\hline 1 weekly online New York times & $\$ 3.45$ \\
\hline
\end{tabular}

Figure 20. Entertainment prices in the US customers this way and they have successfully reached their niche market.

\subsection{Lessons about copyright flexibility and payment}

\section{a) New copyright licensing}

Similar to the fluidity of distribution in the movie industry, a new licensing system is needed to release movies and TV shows faster.

The newspaper industry should not be afraid to lose some rights. The entertainment industry now manages producer and artist rights in a more flexible way without losing all their rights and royalties. All stakeholders are going to win if more movies, newspapers, and music are purchased or rented.

\section{b) Payment models}

The entertainment industry allows users to buy or rent a video a la carte (video on demand, iVOD) or pay a monthly subscription for unlimited content (Netflix or Amazon Prime Video). Users may cancel their subscriptions easily. News- 
papers should explore various models for online access and use the entertainment industry as a model. Online access to one product can generate consumer interest in another, for example, one-click by Amazon; Amazon Prime Instant Video (\$79 per year); and Netflix trial period are good "hooks" to grab consumer attention and entice additional transactions.

\section{c) Extend the life of the product}

The life cycle of a movie or TV show is much longer than newspapers; printed newspapers are "ephemeral", meaning they last just one day, but online their value doesn't end after the last edition is printed and sold. On the contrary, thanks to the digital transition, when a reader turns on a tablet or connects to an app, no matter the time of the day, the newspaper is accessible. Digital journalism brings $24 / 7$ newspapers; so it is still a commodity delivered within a day, and can be part of a database later.

We suggest newspapers could be the new encyclopedias, the "silos" students could refer to for their homework, or source material for professionals to validate their assumptions and be more culturally literate. Everyone loves Wikipedia, but professors would prefer to see students quoting past issues of newspapers.

\subsection{Lessons on multiproduct experience}

To be in the new living room

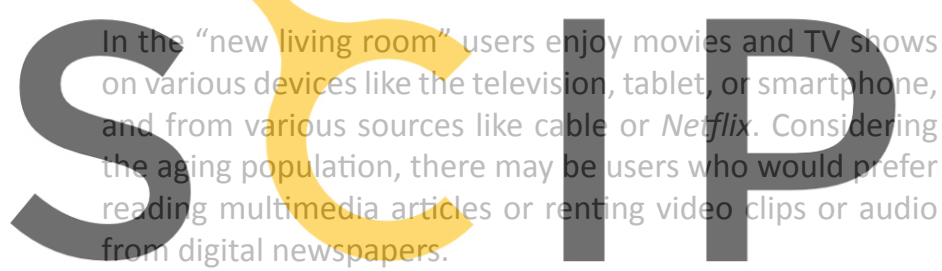

Bundling

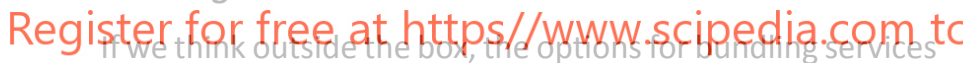

are endless. Options might include packaging newspaper and TV series together or a newspaper subscription along with ten ebooks. Experiences such as Amazon's Newsstand, iTunes TV catalogue, and the Orbyt (paid digital brand of ElMundo.es) have merged a variety of media audiences that were traditionally different. This is just the beginning of the definitive digital transition.

\section{Glamour, branding}

House of Cards is a good example of an innovative television production garnering awards and attention. Hulu and Netflix are intentionally "packaging" movies and TV series to be attractive for moviegoers.

\section{Conclusions}

We are under a new paradigm of media, production, and distribution of content. As Tobbacola says in Turow (2012):

"Now we've got this explosion of content flying around: distribution is disaggregated from content, and everything is moving fast. So media firms are trying to re-aggregate their ability to reach audiences, but now with mass customization."

Two examples of this new paradigm are Yahoo! Politics (Turow, 2011, p. 117) distributing a video created by the Washington post and Google pointing to a The New York times article. Although separate production and distribution was in existence before the rise of digital, now it has become the norm. Today's users don't want to be just buyers of legacy periodicals; they want personalized and relevant content at their fingertips.

Following is our methodology which is based on three business models (figure 21) -a la carte models, subscription, models and pay TV with free access-. Our estimation is that this model could be adapted by the press.

\begin{tabular}{|c|c|c|}
\hline \multicolumn{2}{|c|}{ Transactional } & \multirow{2}{*}{ 3. Subscription models } \\
\hline 1. A la carte & 2. Micropayments & \\
\hline $\begin{array}{l}\text { (Occasional or s } \\
\text { Per issue } \\
\text { Per news } \\
\text { Per day }\end{array}$ & radical readers) & $\begin{array}{l}\text { Paper }+ \text { free online access } \\
\text { Only online } \\
\text { Premium content: } \\
\text { online + special newsletters } \\
\text { online + music + video }\end{array}$ \\
\hline
\end{tabular}

Figure 21. News services types

We conclude that although the initial outlook for newspapers may be bleak the future looks more promising upon closer inspection. One lesson that can be learned from the entertainment industry is that there is life after content becomes free online. There may be an unexplored segment of digital content consumers which would allow future growth in digital newspapers. These consumers are easy to ident
fy-they are subscribers to digkal services such as Nefflix
and spotify. The key assumption is these cligital corsurnels
have a voracious appetite for content in all its forms and
they want to be in control of when and how they consume
that content. As discussed, there is at least some preliminary data that supports this assertion.

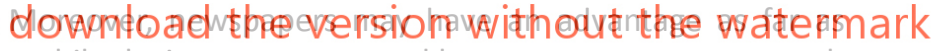
mobile devices are concerned because many consumers already prefer to read news on a mobile device. If the industry can expand rapidly into the mobile market, there may be a way to grow as evidenced by the success of the USA Today app. Granted the future is uncertain, but hopefully there is a fruitful digital road ahead.

\section{Acknowledgement}

This paper is partly financed by the R\&D Project Ref. CSO2011-29510-C03-030 funded by the Spanish Ministry of Economy and Competitivity entitled "Survival of journalism in post-digital era. Media content production and consequences of the participation and development of audiences". A previous study of Digital Journalism Users also was presented by Elvira García de Torres, Concha Edo, and Loreto Corredoira (2012).

\section{Notes}

1. Presented at $15^{\text {th }}$ Intl symposium on online journalism, UT Austin, USA, 2014. We appreciate specially deep comments on it from prof. Pennelope Muse Abenarthy, Knight Chair in Journalism and digital media economics (Chapell Hill, NC) as well as interviews hold with Marty Baron, Washington Post Editor; Caroline Little, NAA Chair; and Juan Angulo, former Warner Bros Spain CEO, which have enlighten our conclusions. 
2. Death of the newspaper industry, The European, 17 Jan 2013. http://www.theeuropean-magazine.com/951-collinsrichard/952-death-of-the-newspaper-industry

Quo vadis Europa? Workshop One EU - many publics?, Stirling, 5-6 February 2004.

http://www.sv.uio.no/arena/english/research/projects/ cidel/old/WorkshopStirling/PaperTrenz.pdf

Who killed the newspaper? The economist, 2006.

http://www.economist.com/node/7830218

Fear and media - how many bad news can people bear? European Editors Forum, 2012.

http://enc.newsroom.de/lang/en/archiv-archive/2012-2/ themen-2012themes-2012

3. Most pirated movies in 2013.

http://torrentfreak.com/the-hobbit-most-pirated-filmof-2013-131231

4. PriceWaterhouseCooper. Outlook for the global sports market about incomes, media rights and sport internationalization. North America is the largest region with US\$ 49.9 billion or $41 \%$ of global revenues in 2010 . Projected to grow at $4.0 \%$ CAGR (compound annual growth rate) to 2015. Gate revenues are the largest sector at $31.4 \%$ in 2010 . Sponsorship is the fastest growing sector to 2015 at $6.1 \%$.

http://www.pwc.com/en_gx/gx/hospitality-leisure/pdf/ changing-the-game-outlook-for-the-global-sports-market-

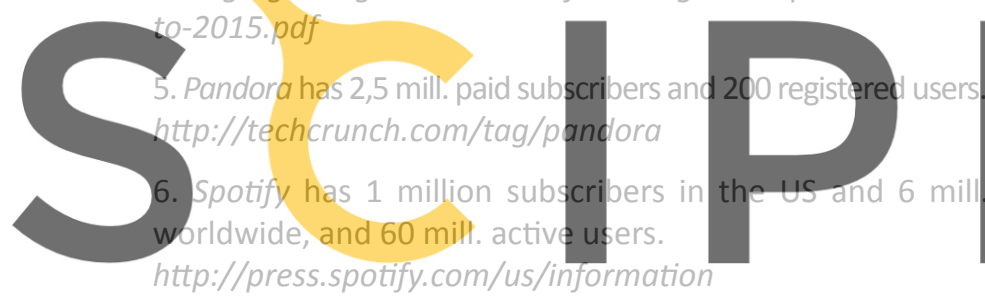

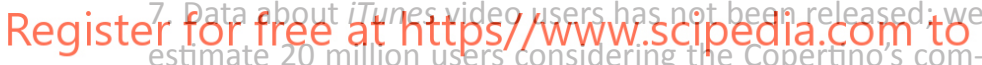
pany has the double of market share than Amazon Prime in ivOD (rentais).

8. Newspaper Association of America (NAA). Press release February 2014. Available to members only.

http://goo.gl//H2J79

9. Mark Thompson (Feb, 2014) at Wall Street following the release of the Times' fourth-quarter financial results, Times chief lays out 'a critical year' for ad revenue (CapitalNews. com)

http://www.capitalnewyork.com/article/media/2014/02/8539943/ times-chief-lays-out-critical-year-ad-revenue

10. Data from "The New York Times Co. Reports 2012 Fourth quarter and full year results." The New York Times Company, press release. Feb. 7, 2013.

http://goo.gl/ngYSwe

11. SenseMaker report by the Newspaper Association of America assesses the latest data on consumption from Scarborough Research, which surveys some 206,000 U.S. adults. Mobile boosts digital newspaper audience 27 percent; 7 in 10 adults access content from newspaper media each week. Available to members.

http://www.naa.org/Trends-and-Numbers/SenseMakerReports.aspx
12. Interviewed by Jennifer Hicks at Forbes (3/30/2013), http://www.forbes.com/sites/jenniferhicks/2013/03/30/ mojivas-ceo-gives-tablets-their-day-in-the-sun

13. "The state of mobile news consumption". Dec, 42012. Number of paid transactions (according to Home entertainment tracker cited in The state of the media: The US entertainment consumer report, May 1, 2013).

\section{Bibliography}

AEDE (Asociación de Editores de Diarios), 2013. Libro blanco de la prensa diaria. Madrid: IESE - AEDE.

http://www. ieseinsight.com/fichaMaterial. aspx?pk=98738\&idi=1\&origen $=1$

Arnold, Thomas K. (2012). "Home entertainment spending up for first time since 2007". The Hollywood reporter, 26 Oct. 2012.

http://www. hollywoodreporter.com/news/homeentertainment-spending-up-first-383447

Beaujon, Andrew (2012). ABC: Newspaper circulation rose in last six months, $5 \%$ on Sundays. May $1^{\text {st }}$. Poynter.com. http://www.poynter.org/news/mediawire/172294/abcnewspaper-circulation-rose-in-last-six-months-5-on-sundays

Casadesus-Masanell, Ramon; Zhu, Feng (2012): “Business model innovation and competitive imitation: the case of

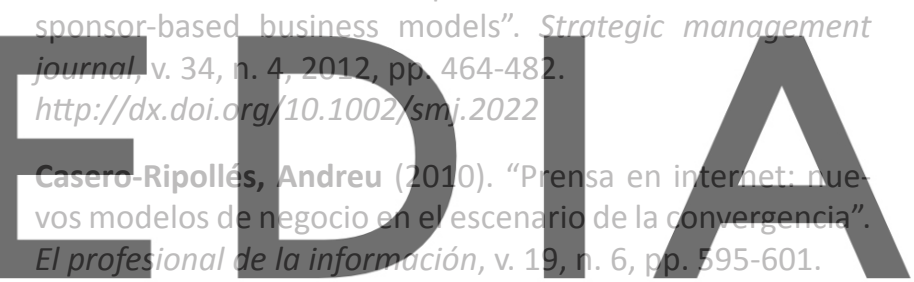
http://dx.doi.org/10.3145/epi.2010.nov05

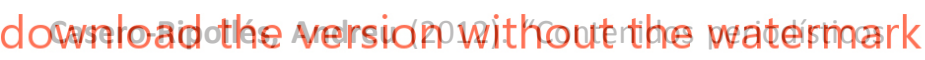
y nuevos modelos de negocio: evaluación de servicios digitales". El profesional de la información, v. 21, n. 4, 2012, pp. 341-346.

http://dx.doi.org/10.3145/epi.2012.jul.02

Corredoira, Loreto (2010). "Los derechos de autor de las obras periodísticas en soportes multimedia (IPAD, SmartPhones, etc.)". Revista de comunicación, n. 9, pp. 111-132.

Corredoira, Loreto (2011). La protección del talento. Valencia: Tirant lo Blanc, 207 pp. ISBN: 9788490045510

Corredoira, Loreto (2011). “¿Porqué Internet es la salvación del cine?". Cyberlaw clinic, Feb.

http://cyberlaw.ucm.es/expertos/loreto-corredoira/108-iporque-internet-es-la-salvacion-del-cine-varias-respuestas.html

Corredoira, Loreto; Sood, Sanjay (2015). The impact of digital technologies on the paid content market: The Netflix paradigm, Technical note, IESE Publishing, March 2015.

http://www.iesep.com/es

Danaher, Brett; Waldfogel, Joel (2012). Reel piracy: the effect of online film piracy on international box office sales. Working paper.

http://dx.doi.org/10.2139/ssrn.1986299 
Dans, Enrique (2014). It's just a question of availability and price, March.

https://medium.com/enrique-dans/its-just-a-question-ofavailability-and-price-825d8e62dec

Dawson, Ross, cited by Manchón, Manel (2013). "Los periódicos de papel morirán en 30 años". Economía digital, March.

http://futureexploration.net/Newspaper_Extinction_ Timeline.pdf

http://www.economiadigital.es/es/notices/2013/03/a_ los_periodicos_de_papel_les_quedan_menos_de_30_ anos_39098.php

Edmonds, Rick; Guskin, Emily; Mitchell, Amy; Jurkowitz, Mark (2013). "Newspapers: stabilizing, but still threatened". The state of the news media 2013. Pew Research Center's Project for Excellence in Journalism. State of the News Media 2013.

http://www.stateofthemedia.org/2013/newspapersstabilizing-but-still-threatened

Fritz, Ben (2014). "Sales of digital movies surge". Wall Street journal.

http://online.wsj.com/news/articles/SB1000142405270230 4887104579306440621142958

García-De-Torres, Elvira; Edo-Bolós, Concha (2012). “Participatory journalism and copyright: policies that regulate user-generated content by news media, companies". Ecrea
2012. $4^{\text {th }}$ European communication conf.

https://commlawpolicy.files.wordpress.com/2012/11/ ecc12_clp_program.pdf

Goyanes-Martínez, Manuel (2012), “Estrategias de pago por contenidos de la prensa digital: una aproximación teórica". Index, v. 2, n. 1.

http://journals.sfu.ca/indexcomunicacion/index.php/ indexcomunicacion/article/view/35

Goyanes-Martínez, Manuel; Peinado-Miguel, Fernando (2014). "Online newspapers business models in Spanish scientific journals: a review and suggestions for future research". Ámbitos: Revista internacional de comunicación, n. 24, pp. 91-100.

http://ambitoscomunicacion.com/2014/online-newspapersbusiness-models-in-spanish-scientific-journals-a-review-andsuggestions-for-future-research

Picard, Robert (2006). Journalism, value creation and the future of news organizations. Havard University.

Rovi Corporation (2013). Consumer mobile streaming survey, Feb 25.

http://goo.gl/sKoXH2

Sood, Sanjay; Corredoira-Alfonso, Loreto (2015). The Impact of Digital Technologies on the Paid Content Market. IESE Publishing, Technical Note, MN-384-E, March, 2015.

Turow, Joseph (2012). The daily you. Yale: Yale University Press, 256 pp. ISBN: 9780300165012

\section{Seminario E[3

- La influencia del Ranking de Shangai (ARWU) en el gobierno de las universidades

- CRIS+IR=FUTUR. El portal de la investigación y de los investigadares de la UPC

- Convertis. El sistema de infarmación científica de Thomson Reuters

- UGRinvestiga: un portal donde convergen la evaluación y la difusión de la investigación

- Métricas Snowball y su aplicación a la evaluación del impacto desde una perspectiva CRIS

- The bibliometric evaluation of monographs: limitations and alternatives

- BiPublishers: La primera propuesta internacional y multidisciplinar para la evaluación bibliométrica de editoriales

- Indicadares para un Sello de Calidad UNE de las Editoriales Universitarias

- Mesa debate: La evaluación de la investigación en ANECA y CNEAI

- Evaluación de la investigación con Gougle Scholar: Sí, se puede

\section{Ponentes del Seminario}

Domingo Dacampo - Jardi Serrano - Pablo de Castro - Clara Núñez - Gonzalo Martos Martínez Sebastian Valley - Thed N. van Leeuwen - Rafael Ruiz Pérez - Emilio Delgado López-Cózar Evaristo Jiménez Contreras - Daniel Torres Salinas - Nicolás Robinson

Drganiza

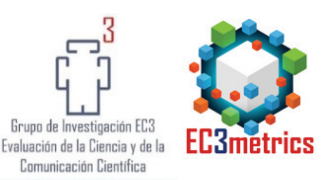

Patrocina
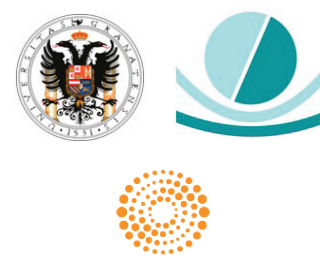

THOMSON REUTERS

El profesional de la información- 